\title{
Erosion control blankets, organic amendments and site variability influenced the initial plant community at a limestone quarry in the Canadian Rocky Mountains
}

\author{
A. C. Cohen-Fernández and M. A. Naeth \\ Department of Renewable Resources, 751 General Services Building, Faculty of Agricultural, Life and Environmental \\ Sciences, University of Alberta, Edmonton, AB, T6G 2H1, Canada \\ Correspondence to: A. C. Cohen-Fernández (anayansi.cohenfernandez@ales.ualberta.ca)
}

Received: 11 October 2012 - Published in Biogeosciences Discuss.: 19 February 2013

Revised: 13 June 2013 - Accepted: 26 June 2013 - Published: 31 July 2013

\begin{abstract}
Season of seeding and soil amendment with manure mix, wood shavings and erosion control blankets were evaluated over two growing seasons to determine their effect on soil properties and native grass establishment at a Canadian limestone quarry and lime processing plant. A season (fall, spring) of soil amending and seeding did not significantly affect revegetation or soil properties. Site characteristics such as slope, aspect, initial soil nutrients and surrounding plant communities influenced early plant community development and overall effects of soil treatments. Erosion control blankets resulted in the highest seeded plant cover and the lowest non-seeded plant cover despite not significantly changing soil chemical properties. Total nitrogen and carbon significantly increased establishment of seeded grasses and non-seeded species. Increased nitrogen and carbon in the constructed soils were best achieved through addition of manure. Wood shavings did not favour establishment of vegetation and resulted in similar, and in some cases less, vegetation than the controls. Assisted revegetation increased plant cover from $<6$ to $50 \%$ and reduced cover of non-seeded species. Amendments that modified both chemical and physical soil conditions were best to increase vegetation establishment in the harsh conditions of the quarry.
\end{abstract}

\section{Introduction}

Limestone, a sedimentary rock of mainly calcium carbonate, is widely used in a variety of industries including construction, metallurgic, pharmaceutics, food and agricul- ture, with an increasing worldwide production and demand (Kesler, 1994). Limestone mining creates large disturbances that significantly impact soil, vegetation and fauna and result in habitat fragmentation and loss (Sort and Alcañiz, 1996; Clemente et al., 2004; Moreno-Peñaranda et al., 2004). Reclamation of limestone quarries, despite being an environmental necessity and mandatory in many countries, has had limited success (Bonifazi et al., 2003; Allen et al., 2005), particularly when the goal is to achieve predisturbance conditions (Wunderle, 1997).

Reclamation can succeed when soil is placed on rock spoil; however, soil for limestone quarry reclamation is scarce, coarse and nutrient deficient (Bradshaw and Chadwick, 1980; Davis et al., 1985). Soil quality can be enhanced with organic amendments (Sopper, 1993; Calderón et al., 2005) such as sewage sludge, biosolids and manure, which are plentiful, relatively inexpensive, readily available and reduce the need for landfill disposal. For example, sewage sludge increased plant biomass and cover in a Spanish quarry although species richness was lower than without sludge (Moreno-Peñaranda et al., 2004). These created substrates would be classified as anthroposols, azonal soils that have been highly modified or constructed by human activity, and are commonly built after disturbances as part of land reclamation activities (Naeth et al., 2012).

When soil is unavailable, fertilizer can improve growing conditions for vegetation. However, building a suitable substrate with rocky materials requires amelioration of both chemical and physical conditions, as Cohen-Fernández and Naeth (2013) identified in greenhouse experiments with 
limestone substrates. Their limestone substrates supported vegetation and could supplement or even substitute for soil. A necessary follow up is field testing, where factors other than substrate quality affect plant establishment. An example of interacting factors in a limestone quarry were identified in the United Kingdom, where plant cover of early seral communities increased up to 15 times that of controls with increased nutrient availability, protection against herbivory and seed input, but only seven times when one or two factors were applied (Davis et al., 1985).

In mined areas, vegetation establishment relies on human augmentation because the seed bank has been removed or damaged; the site can remain relatively unvegetated for decades or can be colonized by unwanted species (Wheater and Cullen, 1997; Cooper and MacDonald, 2000). Native species selection is critical in restoration (Davis et al., 1985; Wunderle, 1997; Alvarez-Aquino et al., 2004; de Souza and Batista, 2004). However, their use is challenging because seeds and propagules are often scarce and expensive, and there is limited information on their responses to nutrients, competing non-native species and seeding season (Gerling et al., 1996; Davis et al., 1998; Riley et al., 2004; Reid and Naeth, 2005; Vieira and Scariot, 2006).

Slope and aspect of contoured embankments, depth and quality of soil covering the embankment, rockiness, potential for soil erosion and gulley formation, age of construction and surrounding vegetation are all factors affecting early ecosystem development. Thus, effects of reclamation treatments must be evaluated within variable quarry structural features. The objective of our research was to determine whether fall and spring soil preparation and seeding, soil amendments and erosion control blankets would contribute to successful establishment of a desired plant community in limestone quarry reclamation.

\section{Materials and methods}

\subsection{Study sites}

Research was conducted at the Graymont Exshaw limestone quarry near Kananaskis, Alberta, Canada $\left(51^{\circ} 07^{\prime} \mathrm{N}\right.$, $115^{\circ} 13^{\prime} \mathrm{W}$ ). The quarry was located on a south facing slope, at $1350 \mathrm{~m}$ elevation, below the $2000-2300 \mathrm{~m}$ tree line. Reclamation research treatments were established on three embankments in the quarry within $1 \mathrm{~km}$ of each other and one at the lime plant $7 \mathrm{~km}$ away. Embankments were engineered piles of limestone mine spoil, covered with topsoil or clean fill (mixed topsoil and subsoil). Site New was on a newly built south facing embankment, approximately $188 \mathrm{~m}$ long and $7-15 \mathrm{~m}$ wide, with a $30^{\circ}$ slope, and covered with $30 \mathrm{~cm}$ of clean fill. Site New HM was a $65 \mathrm{~m}$ long segment covered with 1-2 cm of horse manure. Site Old was on a south facing, older embankment, with $30^{\circ}$ slopes of varying length and covered with $60 \mathrm{~cm}$ of clean fill. Site Plant was on a north- west facing berm with $15-20^{\circ}$ slopes of $10-30 \mathrm{~m}$ lengths covered with $30 \mathrm{~cm}$ of clean fill. These sites collectively represented the heterogeneity of conditions found around the world on typical limestone quarries requiring reclamation.

Climate is montane-subalpine (Alberta Parks and Protected Areas, 2002). Long-term mean annual precipitation is $296.2 \mathrm{~mm}$ as rain and $234.1 \mathrm{~cm}$ as snow. Mean daily temperature is $3{ }^{\circ} \mathrm{C}$; maximum temperature is $21.9^{\circ} \mathrm{C}$ in July and minimum is $-14.1^{\circ} \mathrm{C}$ in January (Environment Canada, 2011a). Mean June temperatures were 4.4 and $11.2^{\circ} \mathrm{C}$ in 2008 and 2009, respectively; October temperatures were 0.1 and $0.7^{\circ} \mathrm{C}$. June to October precipitation was $355.1 \mathrm{~mm}$ in 2008 and $265.7 \mathrm{~mm}$ in 2009 (Environment Canada, 2011b).

In undisturbed surrounding areas, soils are mainly Brunisolic according to the Canadian System of Soils Classification (Soil Classification Working Group, 1998) and Cambisols following the FAO and World Reference Base System (Smith et al., 2011), with calcareous parent material. Vegetation is coniferous and deciduous forest (Alberta Parks and Protected Areas, 2002). Prior to amendment, soil without rocks in the upper $10 \mathrm{~cm}$ was loam textured (Table 1). Electrical conductivity, $\mathrm{pH}$ and sodium adsorption ratio met soil quality criteria guidelines; organic carbon was low $(0.5-1.5 \%)$. Soil properties were similar among sites, except for New HM which had highest nutrients, sodium adsorption ratio and electrical conductivity and lowest organic carbon.

\subsection{Experimental design}

In August 2007, $1402.25 \mathrm{~m}^{2}(1.5 \mathrm{~m} \times 1.5 \mathrm{~m})$ of research plots were established, in a horizontal line, with $1 \mathrm{~m}$ buffers between plots. Half the plots at each site were randomly selected for fall and half for spring soil preparation and seeding. Within spring and fall treatments, soil treatments were randomly assigned. Each treatment, including a control, was replicated 5 times. New, Old and Plant sites had 2 seeding seasons $\times 4$ soil treatments $\times 5$ replicates $=40$ plots . New HM treatments were erosion control blankets and a control for 2 seeding seasons $\times 2$ soil treatments $\times 5$ replicates $=20$ plots.

\subsection{Soil treatments}

Amendments that improved physical and chemical properties of limestone substrate and had adequate plant establishment in a previous greenhouse study, and that were locally available and could be used without an environmental application permit were evaluated in the field. Soil treatments including a control were used in combination with fertilizer, which improved plant establishment in the greenhouse and is a regular practice in other types of quarry reclamation when substrates have low to no nutrients. Erosion control blankets were used to physically protect soil and seeds. The erosion control blanket was Nilex SC150BN of coconut and straw. Cattle manure 
Table 1. Chemical and physical properties of the soil at Exshaw quarry research sites in August 2007 prior to application of treatments.

\begin{tabular}{|c|c|c|c|c|}
\hline \multirow{2}{*}{ Parameter } & \multicolumn{4}{|c|}{ Site } \\
\hline & New & New HM & Old & Plant \\
\hline Total Carbon $(\%)$ & 6.9 & 6.5 & 6.9 & 7.6 \\
\hline Inorganic Carbon $(\%)$ & 5.8 & 5.9 & 6.3 & 6.1 \\
\hline Total Organic Carbon $(\%)$ & 1.0 & 0.5 & 0.6 & 1.5 \\
\hline Inorganic Carbon $/ \mathrm{CaCO}_{3}$ Equivalent (\%) & 5.8 & 5.9 & 6.2 & 6.1 \\
\hline $\mathrm{CaCO}_{3}$ Equivalent (\%) & 48.8 & 49.8 & 52.7 & 51.1 \\
\hline Total Kjeldahl Nitrogen (\%) & 0.1 & 0.1 & 0.1 & 0.1 \\
\hline Available Nitrate Nitrogen $\left(\mathrm{mg} \mathrm{kg}^{-1}\right)$ & 10.2 & 14.0 & 5.4 & 3.6 \\
\hline Available Phosphate Phosphorus ( $\left.\mathrm{mg} \mathrm{kg}^{-1}\right)$ & 2.0 & 2.0 & 2.0 & 2.0 \\
\hline Available Potassium $\left(\mathrm{mg} \mathrm{kg}^{-1}\right)$ & 67 & 304 & 77 & 50 \\
\hline Available Sulfate Sulfur $\left(\mathrm{mg} \mathrm{kg}^{-1}\right)$ & 123 & 257 & 120 & 16 \\
\hline Soluble Chloride $\left(\mathrm{mg} \mathrm{L}^{-1}\right)$ & 20 & 370 & 20 & 40 \\
\hline Soluble Calcium $\left(\mathrm{mg} \mathrm{L}^{-1}\right)$ & 89 & 149 & 87 & 100 \\
\hline Soluble Potassium $\left(\mathrm{mg} \mathrm{L}^{-1}\right)$ & 6 & 169 & 5 & 5 \\
\hline Soluble Magnesium $\left(\mathrm{mg} \mathrm{L}^{-1}\right)$ & 25 & 59 & 21 & 31 \\
\hline Soluble Sodium $\left(\mathrm{mg} \mathrm{L}^{-1}\right)$ & 22 & 82 & 13 & 29 \\
\hline Sodium Adsorption Ratio & 0.5 & 1.4 & 0.3 & 0.7 \\
\hline Sulphate $\left(\mathrm{mg} \mathrm{L}^{-1}\right)$ & 90 & 123 & 49 & 90 \\
\hline Water Saturation (\%) & 28.1 & 28.6 & 26.0 & 27.9 \\
\hline Hydrogen Ion Activity (pH) & 7.6 & 7.5 & 7.6 & 7.7 \\
\hline Electrical Conductivity $\left(\mathrm{dS} \mathrm{m}^{-1}\right)$ & 0.6 & 1.7 & 0.5 & 0.6 \\
\hline Cation Exchange Capacity (m eq $100 \mathrm{~g}^{-1}$ ) & 8.4 & 6.0 & 11.4 & 8.2 \\
\hline Sand $(\%)$ & 50 & 43 & 50 & 51 \\
\hline Silt $(\%)$ & 32 & 39 & 32 & 35 \\
\hline Clay (\%) & 18 & 18 & 18 & 14 \\
\hline Texture & Loam & Loam & Loam & Loam \\
\hline
\end{tabular}

mix was a 2 yr old $6: 1: 1 \mathrm{mix}$ of manure, waste feed and wood shavings. Wood shavings were fine screened from pine and white spruce wood. Manure was applied at $30 \mathrm{Mg} \mathrm{ha}^{-1}$ and wood shavings at $11.25 \mathrm{Mg} \mathrm{ha}^{-1}$, then incorporated into the soil at $5-10 \mathrm{~cm}$ with rakes and shovels. Slow release fertilizer (14-14-14 nitrogen, phosphorus, potassium) was applied at $1.1 \mathrm{Mg} \mathrm{ha}^{-1}$. Fall plots were amended in August 2007 and spring plots in May 2008. Fertilizer was applied at seeding and erosion control blankets after seeding. Due to extensive bighorn sheep (Ovis canadensis Shaw 1804) grazing, Plantskydd, a biodegradable chemical deterrent, was hand sprayed over the research area in June 2008 and April 2009.

\subsection{Plant species}

A native species mix for rapid establishment and tolerance of dry slopes, rocky sites and alkaline soils was seeded at $42.5 \mathrm{~kg} \mathrm{ha}^{-1}$. Grasses were Poa alpina L. (alpine blue grass) $20 \%$, Agropyron trachycaulum (Link) Maltex H. F. Lewis. (slender wheat grass) $15 \%$, Elymus innovatus Beal. (hairy wild rye) $15 \%$, Festuca saximontana Rydb. (rocky mountain fescue) $15 \%$, Trisetum spicatum (L.) K. Richter variety ARC sentinel (spike trisetum) $15 \%$, Bromus carinatus Hook. and Arn. $10 \%$ (mountain brome grass). The forb was Vicia amer- icana Muhl. ex Willd. (american vetch) 10\%. Fall plots were seeded 8-10 October 2007 and spring plots 13-15 May 2008.

\subsection{Soil property quantification}

To determine soil properties prior to reclamation (August 2007 ), three $0-10 \mathrm{~cm}$ cores were collected at each of three locations, then composited to one sample per site. After reclamation one $0-10 \mathrm{~cm}$ core from each of the 140 research plots was taken from each plot in May 2008 and August 2009, and analysed individually.

Samples were analysed according to Carter (1993) unless otherwise noted. Sodium adsorption ratio (SAR), soluble chloride, calcium, potassium, magnesium, sodium and sulphate, $\mathrm{pH}$ and electrical conductivity were determined in $1: 2$ soil: water saturated paste. Total carbon and nitrogen were determined by combustion, total organic carbon by acid digestion then combustion, total inorganic carbon and total inorganic carbon calcium carbonate equivalent by acid digestion and total organic nitrogen by the Kjeldahl procedure (Kalra and Maynard, 1991). Available nitrate, phosphate and potassium were determined by modified Kelowna extraction and available sulphate by extraction with $0.01 \mathrm{M}$ calcium 
chloride. Cation exchange capacity was determined with barium chloride and particle size distribution with a hydrometer.

\subsection{Vegetation assessment}

Vegetation was assessed 28-30 August 2007, prior to plot establishment and soil treatment, since remnant vegetation from a failed seeding at Old and Plant sites and invading weeds were present in low numbers. Canopy cover by species was visually assessed in $20 \mathrm{~cm} \times 50 \mathrm{~cm}$ quadrats at 10 random locations per site.

Vegetation was assessed 13-15 May 2008, 19-24 May 2009, 11-15 August 2008 and 17-24 August 2009 in $0.5 \mathrm{~m} \times 0.5 \mathrm{~m}$ quadrats at the centre of each of the 140 plots. Density by species and canopy and litter cover were determined. In August 2009, covers of seeded species were assessed. Density of seeded species was assessed to verify survival in August 2010 in spring plots.

\subsection{Statistical analyses}

All analyses were performed with SigmaPlot 12 (Systat Software, 2011). Two-way analysis of variance (ANOVA) and pairwise multiple comparisons (Holm Sidack method) were performed on soil data. Plant density and electrical conductivity data did not comply with normality and equality of variance assumptions, thus permutational ANOVA was performed with PERMANOVA v.1.6 (Anderson, 2001; McArdle and Anderson, 2001) with fixed factors season and amendment. Densities of seeded species due to seeding season were analysed with Mann-Whitney rank sum test for most data and with $t$ test for non-normal data. To identify differences in density of seeded species due to amendments and blankets at each site, fall and spring data were pooled and one way non parametric ANOVA used with fixed factor amendment and four levels (wood, blanket, manure, control). Analysis was based on Bray-Curtis dissimilarities distance; 10000 permutations of raw data were used in all tests. A posteriori pairwise comparisons with PERMANOVA were done for treatments with significant differences. Differences in plant cover, litter cover, and cover and density of species due to amendments and blankets were analysed with oneway ANOVA if data had normal distribution and equal variance and ANOVA on ranks otherwise. Cover of seeded and non-seeded species in the same treatment at each site were compared using the Mann-Whitney U rank sum test.

To investigate vegetation response (seeded and non-seeded species density) to site and soil (total nitrogen, carbon and organic carbon; $\mathrm{pH}$, electrical conductivity), redundancy analyses on Hellinger transformed data were performed. Hellinger transformations (Legendre and Gallagher, 2001) prevent distortion of redundancy analysis results by species with low abundance. Analyses were performed with the statistical package R (version 2.13.0) (R Development Core Team,
2011) and Vegan library (version 1.17-10) (Oksanen et al., 2011).

\section{Results}

\subsection{Fall and spring soil preparation and seeding effects}

Soil chemical properties and plant density were not significantly different between spring and fall treatments in either study year (Tables 2 and 3); plant density was generally numerically higher in fall than spring treatments. Only the Plant site had significantly more plants in fall than spring treatments in 2008 (Table 2), but differences did not persist in 2009.

\subsection{Manure, wood shavings and erosion control blanket effects on soils and vegetation}

Total nitrogen, carbon and organic carbon were significantly higher with manure than in controls. Total nitrogen and organic carbon were almost double that of controls in 2008 (Table 4) and remained higher in 2009 (Table 5). Electrical conductivity was more than twice that of the control in 2008, but a year later differences almost disappeared (Table 5). Total nitrogen, carbon and organic carbon did not follow a discernible trend over time after amendment with wood shavings, although total organic carbon was marginally higher at all sites than the control. Erosion control blankets had little effect on nitrogen and carbon relative to the control but concentrations were often significantly lower than with manure or wood shavings. Soil $\mathrm{pH}$ averaged 8, varying little with time and treatment.

Seeded plant density was generally higher with amendments than in controls (Fig. 1). At the New site in 2008 and 2009 significant differences occurred, being up to twice as high with amendments as in the control. Wood shavings had less effect on plant density than manure and were often similar to controls but lower at the Old site both years. Erosion control blankets had a significant effect across sites and over time. In 2008 plant density was almost twice as high with erosion control blankets than the control at New and New HM sites; by 2009 values were over twice as high. Plant density increased in most treatments and sites from 2008 to 2009, except at the New HM site.

\subsection{Soil properties and quarry location effects on seeded and non-seeded species}

A previous revegetation attempt at Old and Plant sites was highly unsuccessful. Average vegetation cover was 4.9, 2.2, 3.3 and $6 \%$ at New, New HM, Old and Plant sites, respectively. This sparse cover was homogeneously distributed.

Total cover was similar among treatments, except in 2008 when it was significantly higher with manure at the New site and with erosion control blankets at New HM (Fig. 2). 
Table 2. Mean measured soil properties and seeded plant density in fall and spring treatments in 2008.

\begin{tabular}{|c|c|c|c|c|c|}
\hline \multirow{2}{*}{ Parameter } & \multirow{2}{*}{ Season } & \multicolumn{4}{|c|}{ Site } \\
\hline & & New & New HM & Old & Plant \\
\hline \multirow[t]{2}{*}{ Total Carbon (\%) } & Fall & $6.96 \pm 0.05$ & $7.47 \pm 0.18$ & $6.88 \pm 0.07^{\mathrm{a}}$ & $7.69 \pm 0.16$ \\
\hline & Spring & $6.99 \pm 0.08$ & $7.48 \pm 0.15$ & $6.99 \pm 0.08^{b}$ & $7.86 \pm 0.13$ \\
\hline \multirow[t]{2}{*}{ Total Organic Carbon (\%) } & Fall & $0.84 \pm 0.06$ & $1.18 \pm 0.19$ & $0.89 \pm 0.06$ & $1.76 \pm 0.01$ \\
\hline & Spring & $0.90 \pm 0.07$ & $1.11 \pm 0.17$ & $0.96 \pm 0.08$ & $1.75 \pm 0.01$ \\
\hline \multirow[t]{2}{*}{ Total Nitrogen (\%) } & Fall & $0.06 \pm 0.00$ & $0.14 \pm 0.02$ & $0.07 \pm 0.00$ & $0.10 \pm 0.01$ \\
\hline & Spring & $0.07 \pm 0.00$ & $0.13 \pm 0.02$ & $0.09 \pm 0.00$ & $0.12 \pm 0.01$ \\
\hline \multirow[t]{2}{*}{ Electrical Conductivity $\left(\mathrm{dS} \mathrm{m}^{-1}\right)$} & Fall & $0.20 \pm 0.01$ & $0.44 \pm 0.03$ & $0.23 \pm 0.01$ & $0.29 \pm 0.01^{\mathrm{a}}$ \\
\hline & Spring & $0.33 \pm 0.06$ & $0.42 \pm 0.05$ & $0.37 \pm 0.07$ & $0.48 \pm 0.08^{\mathrm{b}}$ \\
\hline \multirow[t]{2}{*}{ Hydrogen Ion Activity $(\mathrm{pH})$} & Fall & $8.14 \pm 0.02$ & $8.25 \pm 0.03$ & $8.2 \pm 0.01$ & $8.28 \pm 0.01$ \\
\hline & Spring & $8.15 \pm 0.01$ & $8.22 \pm 0.02$ & $8.19 \pm 0.02$ & $8.29 \pm 0.01$ \\
\hline \multirow[t]{2}{*}{ Density (plants $\mathrm{m}^{-2}$ ) } & Fall & $26.75 \pm 4.79$ & $76.64 \pm 11.00$ & $25.77 \pm 3.20$ & $85.15 \pm 10.60^{\mathrm{a}}$ \\
\hline & Spring & $21.02 \pm 5.17$ & $60.96 \pm 4.99$ & $17.51 \pm 2.39$ & $52.55 \pm 4.80^{\mathrm{b}}$ \\
\hline
\end{tabular}

Values are mean \pm standard error. Values of \pm 0.00 in the table were $<0.006$.

Letters indicate statistically significant differences between fall and spring treatments of the same site. Absence of letters indicates no statistical differences.

Table 3. Mean measured soil properties and seeded plant density in fall and spring treatments in 2009.

\begin{tabular}{|c|c|c|c|c|c|}
\hline \multirow{2}{*}{ Parameter } & \multirow{2}{*}{ Season } & \multicolumn{4}{|c|}{ Site } \\
\hline & & New & New HM & Old & Plant \\
\hline \multirow[t]{2}{*}{ Total Carbon (\%) } & Fall & $7.25 \pm 0.06$ & $7.40 \pm 0.12$ & $7.20 \pm 0.11$ & $8.87 \pm 0.24$ \\
\hline & Spring & $7.37 \pm 0.08$ & $7.49 \pm 0.25$ & $7.22 \pm 0.08$ & $9.23 \pm 0.26$ \\
\hline \multirow[t]{2}{*}{ Total Organic Carbon (\%) } & Fall & $1.02 \pm 0.03$ & $1.19 \pm 0.08$ & $0.99 \pm 0.03$ & $1.32 \pm 0.05$ \\
\hline & Spring & $1.03 \pm 0.05$ & $1.21 \pm 0.13$ & $1.06 \pm 0.06$ & $1.31 \pm 0.06$ \\
\hline \multirow[t]{2}{*}{ Total Nitrogen (\%) } & Fall & $0.08 \pm 0.00$ & $0.11 \pm 0.01$ & $0.08 \pm 0.03$ & $0.09 \pm 0.00$ \\
\hline & Spring & $0.09 \pm 0.01$ & $0.11 \pm 0.01$ & $0.08 \pm 0.01$ & $0.08 \pm 0.00$ \\
\hline \multirow[t]{2}{*}{ Electrical Conductivity $\left(\mathrm{dS} \mathrm{m}^{-1}\right)$} & Fall & $0.32 \pm 0.03$ & $0.33 \pm 0.02$ & $0.34 \pm 0.04$ & $0.33 \pm 0.03$ \\
\hline & Spring & $0.40 \pm 0.03$ & $0.35 \pm 0.03$ & $0.32 \pm 0.02$ & $0.37 \pm 0.03$ \\
\hline \multirow[t]{2}{*}{ Hydrogen Ion Activity $(\mathrm{pH})$} & Fall & $8.18 \pm 0.04$ & $8.06 \pm 0.06$ & $8.12 \pm 0.03$ & $8.09 \pm 0.05$ \\
\hline & Spring & $8.05 \pm 0.03$ & $8.10 \pm 0.07$ & $8.12 \pm 0.03$ & $8.06 \pm 0.05$ \\
\hline \multirow[t]{2}{*}{ Density (plants $\mathrm{m}^{-2}$ ) } & Fall & $25.93 \pm 2.68$ & $79.50 \pm 16.34$ & $42.06 \pm 4.41$ & $82.84 \pm 7.91$ \\
\hline & Spring & $24.37 \pm 3.01$ & $39.73 \pm 4.65$ & $43.13 \pm 5.24$ & $65.60 \pm 4.85$ \\
\hline
\end{tabular}

Values are mean \pm standard error. Values of \pm 0.00 in the table were $<0.006$.

Absence of letters indicates no statistical differences.

In 2009 cover of non-seeded species was significantly lower than seeded species at New HM and Plant sites (Fig. 3). Few significant differences occurred between cover of seeded and non-seeded species at New or Old sites. Erosion control blankets resulted in highest seeded cover and lowest non-seeded cover at New HM, Old and Plant sites, significantly increasing desirable species. Seeded species cover increased with manure, being higher than any other treatment at the New site. Wood shavings resulted in more non-seeded than seeded cover at New and Old sites. Controls had more seeded cover at New HM and Plant sites and more non-seeded cover at New and Old sites.

Constrained ordination on density of seeded and nonseeded species across sites indicated a higher effect of site $(F=37.88)$ than soils $(F=6.06)$ or reclamation treat- ments $(F=3.51)$. This explains the low overlap among sites (Fig. 4). Total nitrogen and carbon were soil properties exerting the strongest influence on vegetation. Total nitrogen and electrical conductivity were a stronger influence at the New HM site where Agropyron trachycaulum and Chenopodium album L. (lamb's quarters) were more abundant. Total carbon exerted greater influence at the Plant site, where conditions favoured Trisetum spicatum and Poa alpina L. (alpine blue grass) more than at any other site, and Melilotus spp. was the dominant non-seeded species. Festuca saximontana was most favoured at Old and Plant sites. Among seeded species, Agropyron trachycaulum benefited most from nitrogen; Festuca saximontana and Poa alpina benefited least. Among non-seeded species, Melilotus (sweet clover) benefited most from total carbon and 
Table 4. Mean measured soil properties in soil treatments in 2008.

\begin{tabular}{llccccc}
\hline \multirow{2}{*}{ Site } & Treatment & $\begin{array}{c}\text { Total carbon } \\
(\%)\end{array}$ & $\begin{array}{c}\text { Total organic } \\
\text { carbon }(\%)\end{array}$ & $\begin{array}{c}\text { Total nitrogen } \\
(\%)\end{array}$ & $\begin{array}{c}\text { Hydrogen ion } \\
\text { activity }(\mathrm{pH})\end{array}$ & $\begin{array}{c}\text { Electrical } \\
\text { conductivity } \\
\text { dS m}^{-1}\end{array}$ \\
\hline New & Control & $6.81 \pm 0.05^{\mathrm{b}}$ & $0.68 \pm 0.02^{\mathrm{b}}$ & $0.06 \pm 0.00^{\mathrm{b}}$ & $8.17 \pm 0.04$ & $0.18 \pm 0.01^{\mathrm{b}}$ \\
& Blanket & $6.74 \pm 0.03^{\mathrm{b}}$ & $0.61 \pm 0.04^{\mathrm{b}}$ & $0.05 \pm 0.00^{\mathrm{b}}$ & $8.11 \pm 0.02$ & $0.22 \pm 0.02^{\mathrm{b}}$ \\
& Manure & $7.25 \pm 0.09^{\mathrm{a}}$ & $1.18 \pm 0.09^{\mathrm{a}}$ & $0.10 \pm 0.01^{\mathrm{a}}$ & $8.17 \pm 0.02$ & $0.50 \pm 0.11^{\mathrm{a}}$ \\
& Wood & $7.10 \pm 0.10^{\mathrm{a}}$ & $1.01 \pm 0.08^{\mathrm{a}}$ & $0.06 \pm 0.00^{\mathrm{b}}$ & $8.14 \pm 0.01$ & $0.17 \pm 0.01^{\mathrm{b}}$ \\
\hline \multirow{2}{*}{ New HM } & Control & $7.73 \pm 0.15$ & $1.45 \pm 0.17^{\mathrm{a}}$ & $0.18 \pm 0.02^{\mathrm{a}}$ & $8.25 \pm 0.03$ & $0.48 \pm 0.03$ \\
& Blanket & $7.23 \pm 0.13$ & $0.83 \pm 0.11^{\mathrm{b}}$ & $0.10 \pm 0.01^{\mathrm{b}}$ & $8.22 \pm 0.02$ & $0.38 \pm 0.05$ \\
\hline \multirow{2}{*}{ Old } & Control & $6.73 \pm 0.10^{\mathrm{b}}$ & $0.74 \pm 0.09^{\mathrm{b}}$ & $0.06 \pm 0.00^{\mathrm{b}}$ & $8.16 \pm 0.02$ & $0.18 \pm 0.00^{\mathrm{c}}$ \\
& Blanket & $6.81 \pm 0.09^{\mathrm{ab}}$ & $0.70 \pm 0.09^{\mathrm{b}}$ & $0.07 \pm 0.00^{\mathrm{b}}$ & $8.16 \pm 0.03$ & $0.25 \pm 0.02^{\mathrm{b}}$ \\
& Manure & $7.13 \pm 0.09^{\mathrm{a}}$ & $1.16 \pm 0.08^{\mathrm{a}}$ & $0.11 \pm 0.01^{\mathrm{a}}$ & $8.21 \pm 0.03$ & $0.56 \pm 0.11^{\mathrm{a}}$ \\
& Wood & $7.05 \pm 0.10^{\mathrm{ab}}$ & $1.09 \pm 0.08^{\mathrm{a}}$ & $0.07 \pm 0.00^{\mathrm{b}}$ & $8.24 \pm 0.02$ & $0.19 \pm 0.00^{\mathrm{c}}$ \\
\hline \multirow{2}{*}{ Plant } & Control & $7.69 \pm 0.21$ & $1.46 \pm 0.13^{\mathrm{b}}$ & $0.10 \pm 0.01^{\mathrm{b}}$ & $8.29 \pm 0.01$ & $0.30 \pm 0.02^{\mathrm{b}}$ \\
& Blanket & $7.68 \pm 0.19$ & $1.41 \pm 0.12^{\mathrm{b}}$ & $0.08 \pm 0.01^{\mathrm{b}}$ & $8.27 \pm 0.01$ & $0.30 \pm 0.03^{\mathrm{b}}$ \\
& Manure & $8.06 \pm 0.25$ & $2.59 \pm 0.46^{\mathrm{a}}$ & $0.16 \pm 0.01^{\mathrm{a}}$ & $8.27 \pm 0.01$ & $0.70 \pm 0.14^{\mathrm{a}}$ \\
& Wood & $7.67 \pm 0.18$ & $1.57 \pm 0.14^{\mathrm{b}}$ & $0.10 \pm 0.01^{\mathrm{b}}$ & $8.31 \pm 0.01$ & $0.26 \pm 0.02^{\mathrm{b}}$ \\
\hline
\end{tabular}

Values are mean \pm standard error. Values of \pm 0.00 in the table were $<0.006$ Letters indicate statistically significant differences among treatments in a site. Absence of letters indicates no statistical differences.

Table 5. Mean measured soil properties in soil treatments in 2009.

\begin{tabular}{llccccc}
\hline \multirow{2}{*}{ Site } & Treatment & $\begin{array}{c}\text { Total carbon } \\
(\%)\end{array}$ & $\begin{array}{c}\text { Total organic } \\
\text { carbon }(\%)\end{array}$ & $\begin{array}{c}\text { Total nitrogen } \\
(\%)\end{array}$ & $\begin{array}{c}\text { Hydrogen ion } \\
\text { activity }(\mathrm{pH})\end{array}$ & $\begin{array}{c}\text { Electrical } \\
\text { conductivity } \\
\mathrm{dS} \mathrm{m}^{-1}\end{array}$ \\
\hline New & Control & $7.15 \pm 0.07^{\mathrm{b}}$ & $0.93 \pm 0.03^{\mathrm{b}}$ & $0.07 \pm 0.00^{\mathrm{b}}$ & $8.18 \pm 0.07$ & $0.33 \pm 0.04$ \\
& Blanket & $7.10 \pm 0.07^{\mathrm{b}}$ & $0.90 \pm 0.02^{\mathrm{b}}$ & $0.08 \pm 0.01^{\mathrm{b}}$ & $8.19 \pm 0.05$ & $0.33 \pm 0.05$ \\
& Manure & $7.53 \pm 0.11^{\mathrm{a}}$ & $1.22 \pm 0.07^{\mathrm{a}}$ & $0.11 \pm 0.01^{\mathrm{a}}$ & $8.07 \pm 0.05$ & $0.38 \pm 0.04$ \\
& Wood & $7.45 \pm 0.10^{\mathrm{a}}$ & $1.05 \pm 0.04^{\mathrm{ab}}$ & $0.09 \pm 0.01^{\mathrm{b}}$ & $8.02 \pm 0.05$ & $0.39 \pm 0.04$ \\
\hline \multirow{2}{*}{ New HM } & Control & $7.49 \pm 0.18$ & $1.25 \pm 0.10$ & $0.11 \pm 0.01$ & $8.10 \pm 0.08$ & $0.34 \pm 0.03$ \\
& Blanket & $7.39 \pm 0.22$ & $1.14 \pm 0.11$ & $0.12 \pm 0.01$ & $8.06 \pm 0.06$ & $0.34 \pm 0.02$ \\
\hline \multirow{2}{*}{ Old } & Control & $6.96 \pm 0.05$ & $0.86 \pm 0.03^{\mathrm{b}}$ & $0.07 \pm 0.00$ & $8.20 \pm 0.06$ & $0.32 \pm 0.03$ \\
& Blanket & $7.31 \pm 0.21$ & $0.99 \pm 0.04^{\mathrm{b}}$ & $0.07 \pm 0.01$ & $8.03 \pm 0.06$ & $0.36 \pm 0.06$ \\
& Manure & $7.28 \pm 0.17$ & $1.16 \pm 0.10^{\mathrm{a}}$ & $0.10 \pm 0.01$ & $8.15 \pm 0.03$ & $0.32 \pm 0.04$ \\
& Wood & $7.28 \pm 0.05$ & $1.08 \pm 0.03^{\mathrm{ab}}$ & $0.08 \pm 0.01$ & $8.10 \pm 0.04$ & $0.31 \pm 0.04$ \\
\hline \multirow{2}{*}{ Plant } & Control & $8.56 \pm 0.22$ & $1.26 \pm 0.07$ & $0.07 \pm 0.00^{\mathrm{b}}$ & $8.18 \pm 0.07$ & $0.30 \pm 0.02$ \\
& Blanket & $9.08 \pm 0.33$ & $1.26 \pm 0.05$ & $0.08 \pm 0.00^{\mathrm{b}}$ & $8.16 \pm 0.04$ & $0.32 \pm 0.04$ \\
& Manure & $9.60 \pm 0.42$ & $1.41 \pm 0.09$ & $0.11 \pm 0.01^{\mathrm{a}}$ & $7.97 \pm 0.09$ & $0.39 \pm 0.05$ \\
& Wood & $8.96 \pm 0.40$ & $1.33 \pm 0.11$ & $0.08 \pm 0.00^{\mathrm{b}}$ & $7.99 \pm 0.08$ & $0.40 \pm 0.07$ \\
\hline
\end{tabular}

Values are mean \pm standard error. Values of \pm 0.00 in the table were $<0.006$.

Letters indicate statistically significant differences among treatments in a site.

Absence of letters indicates no statistical differences.

Erucastrum gallicum (Willd.) O. E. Schulz (common dog mustard) least. Chenopodium (goosefoot) species benefitted from total nitrogen.

\section{Discussion}

The limestone quarry disturbance presented a very inadequate environment for reclamation. None of the shallow and poorly developed topsoil remained after quarrying. There was little adsorptive capability in the substrate to retain 


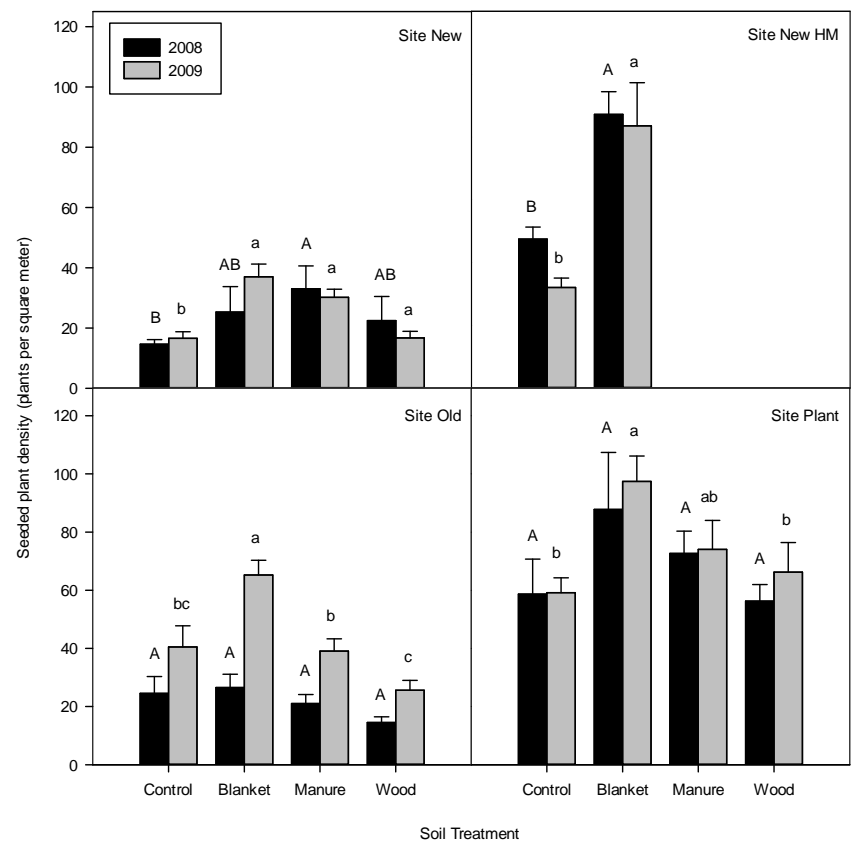

Fig. 1. Mean seeded plant density at each soil treatment and site in 2008 and 2009. Letters indicate significant differences among soil treatments in the same year; upper case letters for 2008 and lower case letters for 2009. Bars indicate standard error.

nutrients even when exogenously provided. The physical and chemical environment was limiting with steep slopes, high $\mathrm{pH}$ and elevated concentrations of calcium carbonates in the soil, which adversely affected potential colonization by plants and development of a functioning, dynamic, soil microbial community. Lack of organic matter to retain and cycle water and nutrients further compromised reclamation. Thus the approach to reclamation was to use erosion control blankets and organic and nutrient amendments to create an anthroposol suitable for plant establishment.

The similar soil conditions and plant responses resulting from fall and spring soil preparation and seeding in our research were unexpected. Differences in soil temperature, water and nutrient availability in spring versus fall were expected to significantly affect reclamation outcomes. The use of good quality amendments in fall soil preparation were expected to create better conditions for germination in spring, with increased water from snowmelt being held in the organically amended substrate. With decomposition and mineralization of the organic material over the first few growing seasons, nutrient availability and further enhanced water holding capacity were expected to ensue. Seeded species could take advantage of snowmelt water to establish before temperatures rise and soil surfaces dry in summer. Fall seeding benefits numerous species (Kilcher, 1961), although others are favoured by spring seeding (Kilcher, 1961; Clayton et al., 2004). Further research is required with a larger number of native plant species to conclude that spring versus fall seed-

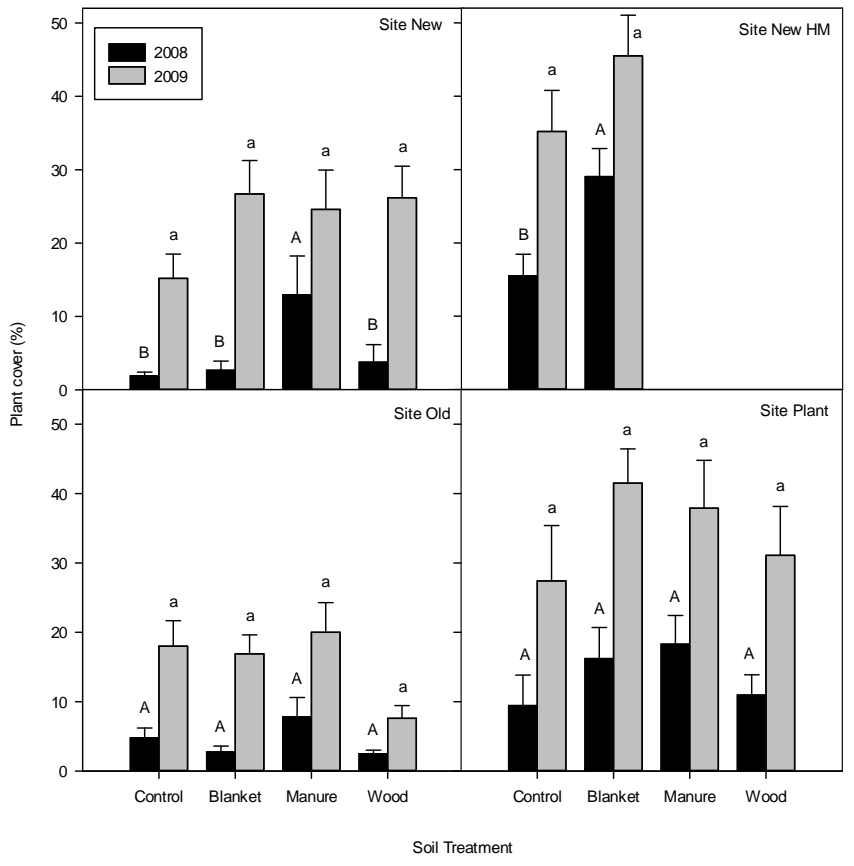

Fig. 2. Mean percent plant cover at each soil treatment and site in 2008 and 2009. Letters indicate significant differences among soil treatments in the same year; upper case letters for 2008 and lower case letters for 2009. Bars indicate standard error.

ing and soil preparation have no effect in these inhospitable quarry sites.

Modifications to both limiting physical and chemical properties of the substrates were important as evidenced by the favourable plant responses to manure, wood and erosion control blankets. Plant density increased with treatments relative to controls, particularly with manure and erosion control blankets. Regardless of the quarry site, these physical and chemical modifications were important to reclamation success.

Erosion control blankets provided a more stable substrate wherein plants could find suitable microsites for establishment on a dry, exposed surface subject to harsh temperatures, drought and wind. Nutrient uptake by the significantly higher number of established plants may explain lower concentrations of total carbon, organic carbon and nitrogen in this treatment. Over time, as decomposition of plant tissue occurs, organic carbon would be expected to increase. The relatively high cover of seeded species and fewer nonseeded species with erosion control blankets was found in other studies (Faucette et al., 2006). Erosion control blankets reduce soil temperature and increase soil water content (Cohen-Fernández and Naeth, unpublished data), creating more favourable conditions for seeded species and reducing the competitive ability of non-native weedy species that normally do well under adverse conditions.

Manure improved substrate chemical properties, such as increased total nitrogen and organic carbon. From this and 
other studies, it is evident manure will improve low quality reclamation soils with low organic matter and nutrients (Saviozzi et al., 1997; Hao et al., 2003; Larney et al., 2006; Yan et al., 2007) and that nutrients will remain high a few years after application. In our study, even though manure was added at a moderate rate, it increased nitrogen which remained high at the end of year 2 . This becomes very important for limestone quarry reclamation, where chemical reactions among highly concentrated carbonates and high $\mathrm{pH}$ of the soil results in immobilized iron oxides, increased nitrification and limited available phosphorus due to phosphate adsorption to carbonate minerals or insolubilization (Kishchuk, 2000). Nutrient limitation likely hindered vegetation in the unamended control. Beneficial results of manure increasing nutrients and plant density were also found in a greenhouse study with amended limestone materials (Cohen-Fernández and Naeth, 2013).

Manure application is well known to significantly increase electrical conductivity in soils (Hao and Chang, 2003). In our study manure amendment was associated with elevated electrical conductivity as expected, particularly with horse manure which resulted in an initial electrical conductivity close to the threshold. However, it had dramatically decreased $1 \mathrm{yr}$ after application, with all values remaining below the $2 \mathrm{dS} \mathrm{m}^{-1}$ threshold for plant establishment (Soil Quality Criteria Working Group, 1987). Although soil water input on site was relatively low, sufficient leaching took place for these salts to be flushed from the system, perhaps as a result of the water from snowmelt.

Plant performance with wood shavings was lower than with manure, similar to results in greenhouse experiments (Cohen-Fernandez and Naeth, 2013). At high rates wood products such as sawdust can reduce nitrogen mineralization and competitive ability of species with higher nitrogen requirements (Averett et al., 2004). This likely happened at Exshaw. Wood shavings would have lower water holding capacity than manure and in general provide less desirable sites for germination.

Site characteristics such as slope, aspect, soil chemistry, availability of limiting resources (Tilman, 1987) and early colonizers that attain dominance (García-Palacios et al., 2011) influence structure and dynamics of plant communities. This study showed the interesting responses of species to specific treatments or treatment combinations. Although these responses were clearly documented, further study is needed to elucidate the varied species responses to individual treatments and their interactions. From our study, we do know how variable these responses can be with site and species used and that they can be significant.

For example, salt tolerance, as measured by electrical conductivity, is species specific with high values potentially inhibiting seed germination or plant growth (Singh et al., 1997). Variable soil chemical properties affect the characteristics of the initial plant community, including species composition. High or low concentrations of nutrients or salts will

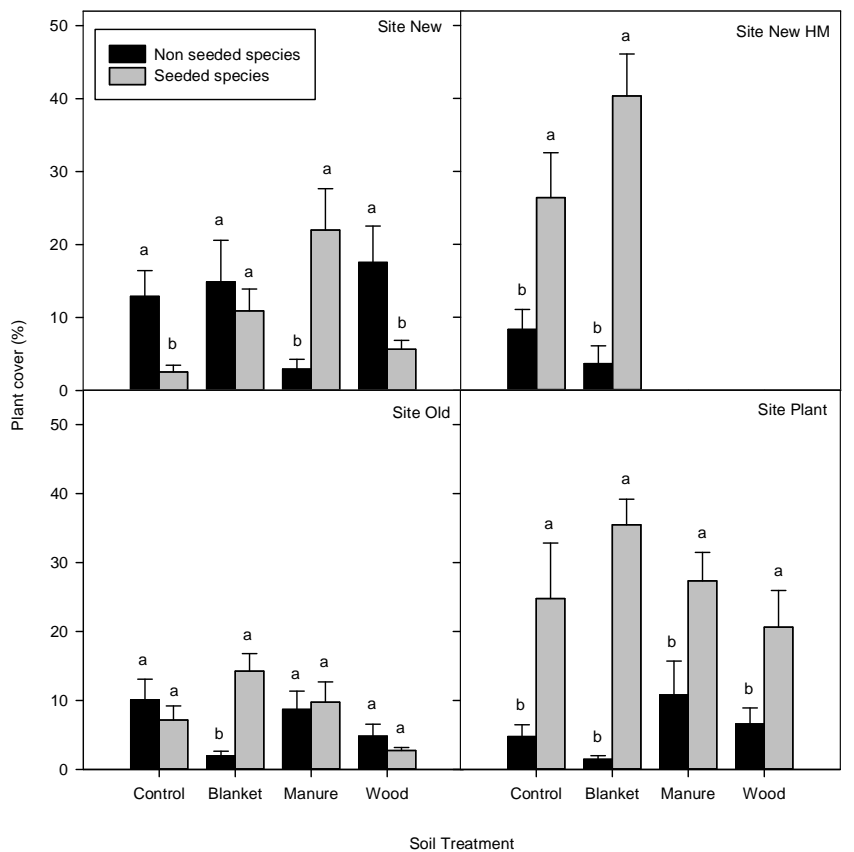

Fig. 3. Mean percent plant cover of seeded and non-seeded species in 2009. Letters indicate significant differences between plant cover of seeded and non-seeded species of the same treatment within a site. Bars indicate standard error.

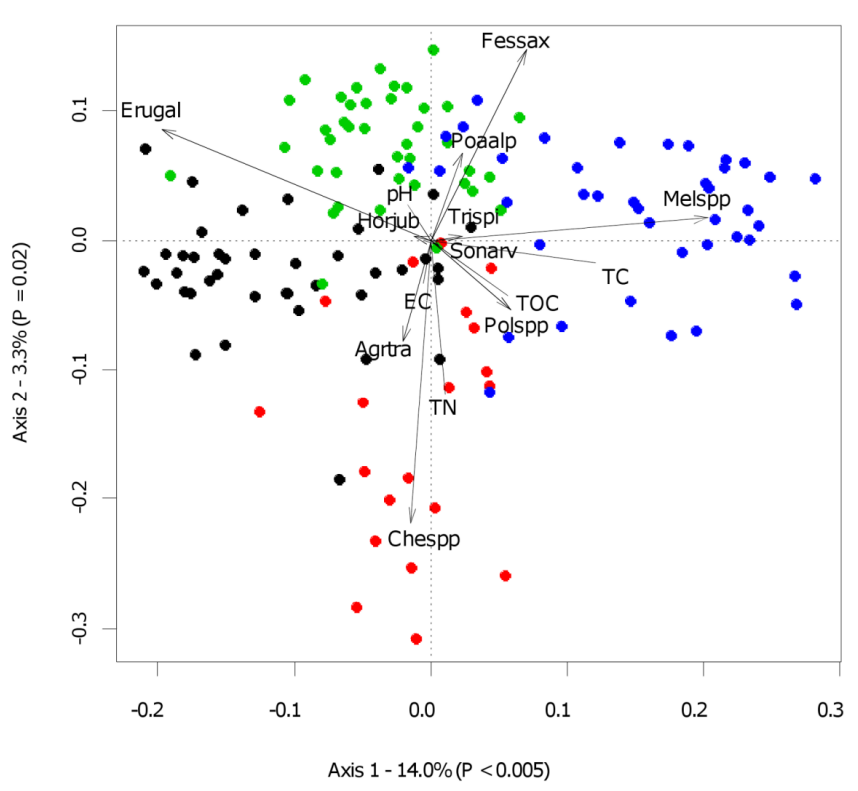

Fig. 4. Triplot of effect of standardized soil properties (lines) on Hellinger transformed species plant density (arrows). Species codes are the first three letters of genus and species names. Plots at each site are in different dot colours: site New, black; site New HM, red; site Old, green; and site Plant, blue. Other soil parameters in the figure are hydrogen ion concentration $(\mathrm{pH})$, total organic carbon (TOC) and electrical conductivity (EC). 
inhibit or facilitate establishment of different species. Even these less than hospitable electrical conductivities were suitable for establishment of Agropyron trachycaulum, whereas Festuca saximontana and Poa alpina established at higher densities at the Plant site, which had lower values.

Erucastrum gallicum, even though it was the most dominant non-seeded species at every site, was drastically reduced with organic amendments and erosion control blankets. This was likely due to the enhanced performance of the seeded species which could them compete with Erucastrum gallicum. Chenopodium album, another non-seeded species, benefited from increased nitrogen. Trisetum spicatum and Poa alpina benefited more at the Plant site with higher total carbon. These species were also favoured by biosolids in the greenhouse (Cohen-Fernández and Naeth, 2013) which increased the substrate's total carbon. Controls often had greater cover of non-seeded than seeded species, confirming the need for amelioration of quarry substrate to achieve a desired early plant community with high cover of seeded species. More favourable sites, such as the northwest facing berm at Plant and New HM sites, provided higher seeded plant density and cover. These responses were also seen in similar harsh sites. For example, soils on north facing slopes on dryland in southeastern Nebraska had $20 \%$ more water throughout the year than south facing slopes (Hanna et al., 1982). In a sandy grassland in Hungary, influence of carbon on nitrogen immobilization was more pronounced at sites where organic matter and water were lowest (Török et al., 2000).

On south facing slopes, New and New HM sites were an interesting comparison. Although located on the same embankment, horse manure yielded denser seeded species. Harsher sites, because of lower nutrients and greater wind exposure (New, Old) had greater non-seeded cover and lower establishment of seeded species. This may not be a threat unless non-seeded species are highly competitive and invasive, because they provide benefits to the early plant community, reducing soil erosion, adding organic matter and buffering temperature. Establishment of certain species in early stages of succession may modify biotic and abiotic conditions of a site, facilitating establishment of more species (facilitation model), or arresting incorporation of new individuals (inhibition model) (Connell and Slatyer, 1977).

Many inhibiting species are not native and are listed as noxious. They are often early successional, regulated (Government of Alberta, 2008) and require monitoring and control or they may inhibit desired species. In early successional stages of herbaceous communities, inhibition will usually dominate and characteristics of pre-existing vegetation will have a large influence on success of species establishment in degraded systems (Gomez-Aparicio, 2009). Sonchus arvensis L. (sow thistle) and Cirsium arvense L. (canada thistle), two of the most frequent, noxious, broad leaved weeds in North America (Skinner et al., 2000), and the grassy weeds Hordeum jubatum L. (foxtail barley) and Avena fatua L. (common oat) were at Exshaw but not in sufficient quantities to significantly reduce seeded species density and cover.

Fertilizer was used with all treatments to increase soil available nitrogen, phosphorus and potassium. In a greenhouse experiment, fertilizer addition increased above and below ground biomass of the same native grasses used in this field experiment (Cohen-Fernandez and Naeth, 2013) and thus its use is desirable during initial revegetation. Nonetheless, fertilization can increase the presence of unwanted species. Nitrates from fertilizer can break dormancy of some weedy species (Sexsmith and Pittman, 1963) which can then compete with native grasses (Huffine and Elder, 1960) and seeded crops (Davis and Liebman, 2001), taking advantage of the added nutrients. In the quarry, however, it is likely that potential problems with unwanted species associated with use of fertilizer may be prevented or modified if using erosion control blankets, moving the community from inhibition to facilitation stages much sooner than without human augmentation. Soil nutrient management over time with fertilizer, amendments and legumes in the seed mix, will contribute nitrogen and other nutrients.

\section{Conclusions}

With erosion control blankets and organic amendments a desirable plant cover was achieved at the limestone quarry as both physical and chemical soil limitations were addressed. Assisted revegetation increased plant cover from $<6$ to $50 \%$ and reduced cover of non-seeded species. Erosion control blankets facilitated denser native grass establishment with less non-seeded species cover, despite not changing chemical properties of constructed soils. Manure was more effective than wood shavings improving soil properties and plant establishment. Differences in spring or fall soil preparation and seeding were not significant for the native species studied. Site characteristics such as slope, aspect and soil nutrients influenced early plant community development and treatment effects. Increasing total nitrogen and carbon in soil will increase density and establishment of seeded and nonseeded species. A combined approach of soil nutrient enrichment with manure and protection with erosion control blankets could further increase revegetation success.

Acknowledgements. Thank you to CONACYT for a scholarship; Graymont Company for research funding, research site and logistical support; Nilex Inc. for erosion control blankets; Brett Young Seeds for seeds.

Edited by: I. Kögel-Knabner 


\section{References}

Alberta Parks and Protected Areas.: Bow Valley protected areas management plan, Government of Alberta, 0-7785-2221-0, Edmonton, Alberta, 2002.

Allen, M. F., Allen E. B., and Gómez-Pompa, A.: Effects of mycorrhizae and nontarget organisms on restoration of a seasonal tropical forest in Quintana Roo, Mexico: factors limiting tree establishment, Restor. Ecol., 13, 325-333, 2005.

Alvarez-Aquino, C., Williams-Linera, G., and Newton, A. C.: Experimental native tree seedling establishment for the restoration of a Mexican cloud forest, Restor. Ecol., 12, 412-418, 2004.

Anderson, M. J.: A new method for non-parametric multivariate analysis of variance, Austral. Ecol., 26, 32-46, 2001.

Averett, J. M., Klips, R. A., Nave, L. E., Frey, S. D., and Curtis, P. S.: Effects of soil carbon amendment on nitrogen availability and plant growth in an experimental tallgrass prairie restoration, Restor. Ecol., 12, 568-574, 2004.

Bonifazi, G., Cutaia, L., Massacci, P., and Roselli, I.: Monitoring of abandoned quarries by remote sensing and in situ surveying, Ecol. Model., 170, 213-218, 2003.

Bradshaw, A. D. and Chadwick, M. J.: The restoration of land: The ecology and reclamation of derelict and degraded land, University of California Press, Berkeley, California, 317 pp., 1980.

Calderón, F. J., McCarty, G. W., and Reeves, J. B.: Analysis of manure and soil nitrogen mineralization during incubation, Biol. Fert. Soils, 41, 328-336, 2005.

Carter, M. R.: Soil sampling and methods of analysis, Lewis Publisher, Boca Raton, Florida, 1993.

Clayton, G. W., Harker, K. N., O’Donovan, J. T., Blackshaw, R. E., Dosdall, L. M., Stevenson, F. C., and Ferguson, T.: Fall and spring seeding date effects on herbicide-tolerant canola (Brassica napus L.) cultivars, Can. J. Plant Sci., 84, 419-430, 2004.

Clemente, A. S., Werner, C., Maguas, C., Cabral, M. S., MartinsLoucao, M. A., and Correia, O.: Restoration of a limestone quarry: effect of soil amendments on the establishment of native Mediterranean sclerophyllous shrubs, Restor. Ecol., 12, 20-28, 2004.

Cohen-Fernandez, A. C. and Naeth, M. A.: Anthroposol development from limestone quarry substrates, Can. J. Soil Sci., accepted, 2013.

Connell, J. H. and Slatyer, R. O.: Mechanisms of succession in natural communities and their role in community stability and organization, Am. Nat., 111, 1119-1144, 1977.

Cooper, D. J. and MacDonald, L. H.: Restoring the vegetation of mined peatlands in the southern Rocky Mountains of Colorado, U.S.A., Restor. Ecol., 8, 103-111, 2000.

Davis, A. S. and Liebman, M.: Nitrogen source influences wild mustard growth and competitive effect on sweet corn, Weed Sci., 49, 558-566, 2001.

Davis, B. N. K., Lakhani, K. H., Brown, M. C., and Park, D. G.: Early seral communities in a limestone quarry: an experimental study of treatment effects on cover and richness of vegetation, J. Appl. Ecol., 22, 473-490, 1985.

Davis, M. A., Wrage, K. J., and Reich, P. B.: Competition between tree seedlings and herbaceous vegetation: Support for a theory of resource supply and demand, J. Ecol., 86, 652-661, 1998.

de Souza, F. M. and Batista, J. L. F.: Restoration of seasonal semideciduous forests in Brazil: influence of age and restoration design on forest structure, Forest Ecol. Manag., 191, 185-200, 2004.
Environment Canada: Banff Station. Canadian climate normals 1971-2000, available at: http://climate.weatheroffice.gc.ca/ climate_normals/results_e.html?stnID=2364\&lang=e\&dCode= $0 \&$ StationName $=\&$ Search Type $=\&$ province $=\&$ provBut $=$ \&dispBack $=\&$ month $1=0 \&$ month $2=12$, (last access: 18 June), 2011a.

Environment Canada: Bow Valley Station. Climate summaries, available at: http://climate.weatheroffice.gc.ca/prods_servs/cdn_ climate_summary_e.html,(last access: 19 December), 2011 b.

Faucette, L. B., Risse, L. M., Jordan, C. F., Cabrera, M. L., Coleman, D. C., and West, L. T.: Vegetation and soil quality effects from hydroseed and compost blankets used for erosion control in construction activities, J. Soil Water Conserv., 61, 355-362, 2006.

García-Palacios, P., Bowker, M. A., Chapman, S. J., Maestre, F. T., Soliveres, S., Gallardo, A., Valladares, F., Guerrero, C., and Escudero, A.: Early-successional vegetation changes after roadside prairie restoration modify processes related with soil functioning by changing microbial functional diversity, Soil Biol. Biochem., 43, 1245-1253, 2011.

Gerling, H. S., Willoughby, M. G., Schoepf, A., Tannas, K. E., and Tannas, C. A.: A guide to using native plants on disturbed lands, Alberta Agriculture, Food and Rural Development, Edmonton, Alberta, 1996.

Gomez-Aparicio, L.: The role of plant interactions in the restoration of degraded ecosystems: a meta-analysis across life-forms and ecosystems, J. Ecol., 97, 1202-1214, 2009.

Government of Alberta: Weed control act, Queen's Printer, Edmonton, Alberta, 2008.

Hanna, A. Y., Harlan, P. W., and Lewis, D. T.: Soil available water as influenced by landscape position and aspect, Agron. J., 74, 999-1004, 1982.

Hao, X. and Chang, C.: Does long-term heavy cattle manure application increase salinity of a clay loam soil in semi-arid southern Alberta?, Agr. Ecosyst. Environ, 94, 89-103, 2003.

Hao, X., Chang, C., Travis, G. R., and Zhang, F.:Soil carbon and nitrogen response to 25 annual cattle manure applications, J. Plant Nutr. Soil Sci., 166, 239-245, 2003.

Huffine, W. W. and Elder, W. C.: Effect of fertilization on native grass pastures in Oklahoma, J. Range Manage., 13, 34-36, 1960.

Kalra, Y. P. and Maynard, D. G.: Methods manual for forest soil and plant analysis, Northern Forestry Center, Forestry Canada, NOR-X-319, Edmonton, Alberta, 57-59, 1991.

Kesler, S. E.: Mineral resources, economics and the environment, Macmillan College Publishing Company, New York, New York, 1994.

Kilcher, M. R.: Fall seeding versus spring seeding in the establishment of five grasses and one alfalfa in southern Saskatchewan, J. Range Manage, 14, 320-322, 1961.

Kishchuk, B. E.: Calcareous soils, their properties and potential limitations to conifer growth in southeastern British Columbia and western Alberta: a literature review. Natural Resources Canada, Canadian Forestry Service and British Columbia Ministry of Forests, Rep. NOR-X-370, Edmonton, Alberta, 2000.

Larney, F. J., Buckley, K. E., Hao, X., and McCaughey, W. P.: Fresh, stockpiled, and composted beef cattle feedlot manure, J. Environ. Qual., 35, 1844-1854, 2006.

Legendre, P. and Gallagher E.: Ecologically meaningful transformations for ordination of species data, Oecologia, 129, 271-280, 
2001.

McArdle, B. H. and Anderson, M. J.: Fitting multivariate models to community data: a comment on distance-based redundancy analysis, Ecology, 82, 290-297, 2001.

Moreno-Peñaranda, R., Lloret, F., and Alcañiz, J. M.: Effects of sewage sludge on plant community composition in restored limestone quarries, Restor. Ecol., 12, 290-296, 2004.

Naeth, M. A., Archibald, H. A., Nemirsky, C. L., Leskiw, L. A., Brierley, J. A., Bock, M. D., VandenBygaart, A. J., and Chanasyk, D. S.: Proposed classification for human modified soils in Canada: Anthroposolic order, Can. J. Soil Sci., 92, 7-18, 2012.

Oksanen, J., Blanchet, F. G., Kindt, R., Legendre, P., Minchin, P. R., O’Hara, R. B., Simpson, G. L., Solymos, P., Stevens M. H. H., and Wagner, H.: Vegan: community ecology package, R package version 1.17-10, 2011.

R Development Core Team.: R: a language and environment for statistical computing, R Foundation for Statistical Computing, Vienna, Austria, 2011

Reid, N. B. and Naeth, M. A.: Establishment of a vegetation cover on tundra kimberlite mine tailings: 2. A field study, Restor. Ecol., 13, 602-608, 2005.

Riley, J. D., Craft, I. W., Rimmer D. L. and Smith, R. S.: Restoration of magnesian limestone grassland: optimizing the time for seed collection by vacuum harvesting, Restor. Ecol., 12, 311317,2004

Saviozzi, A., Levi-Minzi, R., Riffaldi, R. and Vanni, G.: Laboratory studies on the application of wheat straw and pig slurry to soil and the resulting environmental implications, Agr. Ecosyst. Environ., 61, 35-43, 1997.

Sexsmith, J. J. and Pittman, U. J.: Effect of nitrogen fertilizers on germination and stand of wild oats, Weeds, 11, 99-101, 1963.

Singh, S. N., Kulshreshtha, K., and Ahmad, K. J.: Impact of fly ash soil amendment on seed germination, seedling growth and metal composition of Vicia faba L., Ecol. Eng., 9, 203-208, 1997.

Skinner, K., Smith, L., and Rice, P.:Using noxious weed lists to prioritize targets for developing weed management strategies, Weed Sci., 48, 640-644, 2000.
Smith, C. A. S., Webb, K. T., Kenney, E., Anderson, A., and Kroetsch, D.: Brunisolic soils of Canada: Genesis, distribution, and classification, Can. J. Soil Sci., 91, 695-717, 2011.

Soil Quality Criteria Working Group: Soil quality criteria relative to disturbance and reclamation, Alberta Agriculture, Food and Rural Development, Edmonton, Alberta, 1987.

Soil Classification Working Group.: The Canadian System of Soil Classification, Agriculture and Agri-Food Canada Publication 1646, NRC Research Press, Ottawa, 1998.

Sopper, W. E.: Municipal sludge use in land reclamation, Lewis Publishers, London, UK, 1993.

Sort, X. and Alcañiz, J. M.: Contribution of sewage sludge to erosion control in the rehabilitation of limestone quarries, Land Degrad. Dev., 7, 69-76, 1996.

Systat Software.: SigmaPlot for Windows version 12, Systat Software Inc. Chicago, Illinois, 2011.

Tilman, D.: Secondary succession and the pattern of plant dominance along experimental nitrogen gradients, Ecol. Monogr., 57 189-214, 1987.

Török, K., Szili-Kovács, T., Halassy, M., Tóth, T., Hayek, Z., Paschke, M. W., and Wardell, L. J.: Immobilization of soil nitrogen as a possible method for the restoration of sandy grassland, Appl. Veg. Sci., 3, 7-14, 2000.

Vieira, D. L. M. and Scariot, A.: Principles of natural regeneration of tropical dry forest for restoration, Restor. Ecol., 14, 11-20, 2006.

Wheater, C. P. and Cullen, W. R.: The flora and invertebrate fauna of abandoned limestone quarries in Derbyshire, United Kingdom, Restor. Ecol., 5, 77-84, 1997.

Wunderle Jr., J. M.: The role of animal seed dispersal in accelerating native forest regeneration on degraded tropical lands, Forest Ecol. Manag., 99, 223-235, 1997.

Yan, D., Wang D., and Yang, L.: Long-term effect of chemical fertilizer, straw, and manure on labile organic matter fractions in a paddy soil, Biol. Fert. Soils, 44, 93-101, 2007. 